Western Washington University

Western CEDAR

\title{
A Questionnaire Study of Two-Verb Clusters in West Central German
}

Shannon A. Dubenion-Smith

Western Washington University, shannon.dubenion-smith@wwu.edu

Follow this and additional works at: https://cedar.wwu.edu/mcl_facpubs

Part of the German Linguistics Commons, and the Modern Languages Commons

\section{Recommended Citation}

Dubenion-Smith, Shannon A., "A Questionnaire Study of Two-Verb Clusters in West Central German" (2013). Modern \& Classical Languages. 22.

https://cedar.wwu.edu/mcl_facpubs/22

This Article is brought to you for free and open access by the Humanities at Western CEDAR. It has been accepted for inclusion in Modern \& Classical

Languages by an authorized administrator of Western CEDAR. For more information, please contact westerncedar@wwu.edu. 


\title{
A questionnaire study of two-verb clusters in West Central German ${ }^{1}$
}

\author{
Shannon A. Dubenion-Smith \\ Western Washington University
}

Until recently, the West Central German dialect area was largely neglected in investigations of verb clusters. The article presents the results of a questionnaire study of two-verb clusters involving 55 participants in 17 localities in that dialect area. These results indicate that the occurrence of particular orders is subject to interspeaker, intraspeaker, and areal variation as well as morphosyntactic constraints. Furthermore, a comparison of these results with those from a corpus study of the same dialect area suggests diachronic stability in the relative areal distribution of verb clusters over the roughly 50 years since the spoken data for the corpus were collected. Finally, results for the Hessian region of West Central German point toward this area as a particularly promising locus of further research.

Keywords: verb clusters, dialect syntax, West Central German, questionnaire study

\section{Introduction}

During the last several decades, dialect syntax has come into its own as an object of research on par with the more traditionally investigated domains of the lexicon, morphology, and phonology. This increased attention, which has been propelled in part by an interest in microparametric variation from a theoretical perspective (see e.g. Barbiers, Cornips \& Van der Kleij

\footnotetext{
${ }^{1}$ This research was funded by generous support from the DAAD (German Academic Exchange Service). I would like to express my gratitude to colleagues at the Deutscher Sprachatlas in Marburg, especially Alexandra N. Lenz, for their guidance during my research stay from January to June 2007 , and to Jürg Fleischer, Alexandra N. Lenz, Mark L. Louden, and two anonymous reviewers for helpful comments on earlier drafts of this article.
} 
2002), has given rise to numerous works on the syntax of European dialects (e.g. Benincà 1989, Haegeman 1992, Nübling 1992, Penner 1995, Black \& Motapanyane 1996, Patocka 1997, Zanuttini 1997, Weiß 1998, Fleischer 2002, Tortora 2002, Seiler 2003, D'Alessandro, Ledgeway \& Roberts 2010), large-scale syntactic atlas projects (e.g. Atlante Sintattico d'Italia [ASIt], Syntactische Atlas van de Nederlandse Dialecten [SAND], Syntaktischer Atlas der Deutschen Schweiz [SADS], Syntax hessischer Dialekte [SyHD]), and ample treatment in a recently published international handbook on linguistic variation (Auer \& Schmidt 2010).

One of the most widely studied syntactic phenomena in the Continental West Germanic languages and dialects is the verbal complex, clusters of two or more verb forms that display word-order variation. For example, the modal IPP construction in St. Gallen Swiss German displays not only one possible word order like its English equivalent, but three: ${ }^{2}$

(1) a. das de Jonas hät ${ }_{1}$ müese ${ }_{2}$ schwimme $_{3}$ 1-2-3 dass der Jonas hat müssen schwimmen that the Jonas has must swim

b. das de Jonas hät schwimme $_{3}$ müese ${ }_{2} \quad$ 1-3-2

c. das de Jonas schwimme ${ }_{3}$ hät müese $_{2}$ 3-1-2 $^{-2}$ 'that Jonas had to swim' (Schönenberger 1995: 367)

It is the astounding cross-linguistic and system-internal variation in the verbal complex that has made this topic such an attractive one to scholars from various research traditions (see Wurmbrand 2006 for an overview).

Besides the documentation of word-order variation in verbal complexes, two major research foci have been the identification of factors that influence this variation and the theoretical analysis of complexes (see e.g. Lötscher 1978, den Besten \& Edmondson 1983, Haegeman \& van Riemsdijk 1986, Zwart 1996, Koopman \& Szabolcsi 2000, Kiss \& van Riemsdijk 2004, Schmid \& Vogel 2004, de Sutter 2007, Dubenion-Smith 2010, 2011). In addition, both idiolectal and areal variation have been areas of keen interest (see e.g. Seiler 2004, Barbiers 2005, Cornips 2009). However, while verbal complexes in Standard German and Dutch, Upper German and Dutch dialects, as well as Eastern Yiddish (Krogh 2008), Mennonite Low German (Kaufmann 2007), and Pennsylvania Dutch (Louden 2011) have

\footnotetext{
${ }^{2}$ The structural relationship between the verb forms in the complex is indicated by their subscripts, whereby verb 1 subcategories verb 2 , which in turn subcategorizes verb 3 . This convention is used throughout the text.
} 
been relatively well studied, the Central and Low German dialects have been largely neglected in this regard.

Dubenion-Smith (2010), a corpus study of verbal complexes in West Central German (henceforth WCG), helps to fill this gap in the literature. This work, based on transcripts of dialect recordings from the Zwirner Corpus made in the 1950 s and maintained online by the Institut für Deutsche Sprache, ${ }^{3}$ provides data on the distribution of verbal complexes throughout the WCG region and discusses factors that influence word order in the verbal complex. Yet it deals with neither idiolectal nor areal variation. ${ }^{4}$ The main purpose of the present article is therefore to complement DubenionSmith (2010) with data from a questionnaire study of verb clusters in WCG, focusing on the two-verb syntagms participle + auxiliary (e.g. er hat gesagt, dass er in die Stadt gefahren ist $_{1}$ ist $_{1}$ gefahren $_{2}$ 'he said that he has gone into town'; er will wissen, ob der Bürgermeister das Huhn gefunden hat $_{1} /$ hat $_{1}$ gefunden ${ }_{2}$ 'he wants to know if the mayor has found the chicken') and infinitive + modal (er hat gesagt, dass er das Huhn finden ${ }_{2}$ kann $_{1} /$ kann $_{1}$ finden ${ }_{2}$ 'he said that he can find the chicken'). Furthermore, the article may serve as a starting point for additional more comprehensive studies on verbal complex phenomena in the modern WCG dialects and as a point of comparison to new investigations of syntax in the region, such as those carried out under the purview of the atlas project Syntax hessischer Dialekte (SyHD). ${ }^{5}$

The main findings in this article are threefold. First, the participants in the questionnaire study produce both the $2-1$ and $1-2$ orders with the syntagms participle + auxiliary and infinitive + modal; moreover, the occurrence of particular orders is subject to interspeaker, intraspeaker, and areal variation and correlates to the morphosyntax of the cluster, with infinitive + modal displaying more individual variation than participle + auxiliary. Second, a comparison of the results from the questionnaire to data from Dubenion-Smith (2008) suggests diachronic stability in the relative areal distribution of two-verb clusters over the roughly 50 years since the dialect recordings for the Zwirner Corpus were made. Third, the distribution of word orders in the Hessian dialect area points toward this region as a particularly promising locus of further research.

\footnotetext{
${ }^{3}$ See http://agd.ids-mannheim.de/html/dgd.shtml.

${ }^{4}$ Dubenion-Smith (2008), an earlier unpublished work on which Dubenion-Smith (2010) is based, does take these aspects into consideration.

${ }^{5}$ See http://www.uni-marburg.de/fbog/igs/mitarbeiter/fleischer/forschung/syhd and http:// www.syhd.info/.
} 
The remainder of the article is organized as follows. Section 2 provides an overview of the WCG dialect area. The methodology for the questionnaire study, including information on the consultants, measuring points, instrument, procedure, and limitations, is laid out in section 3. Section 4 presents the results of the study with a focus on idiolectal and areal variation, followed by a summary in section 5 .

\section{Dialect area}

WCG belongs to the central region of the High German dialect area bordering on Low German to the north, East Central German to the northeast, and Upper German to the south and southeast.

In Figures 1 and 2 (Wiesinger 1983: 831), WCG comprises Central Franconian (Mittelfränkisch), which can be further subdivided into the Ripuarian

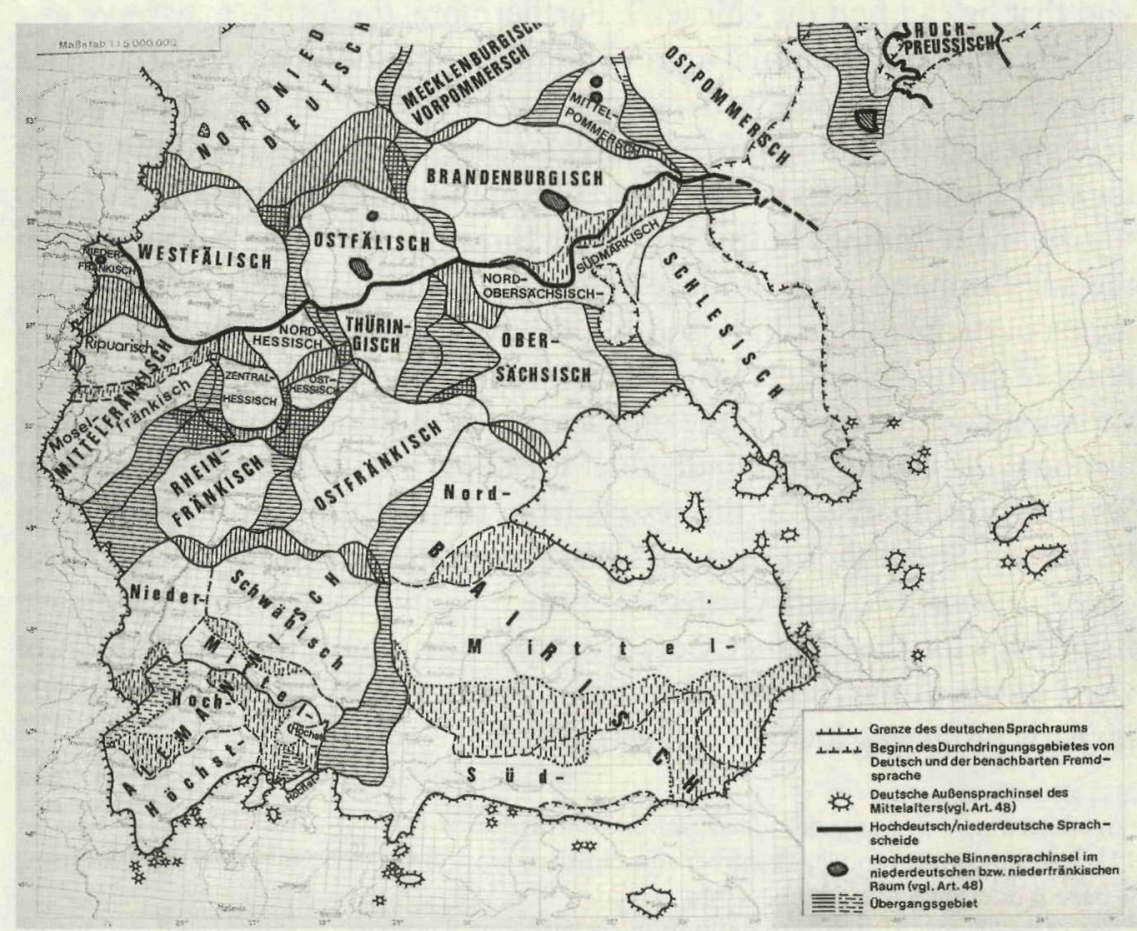

Figure 1. German dialect space, first decades of the 2oth c. (Wiesinger 1983: 831) 


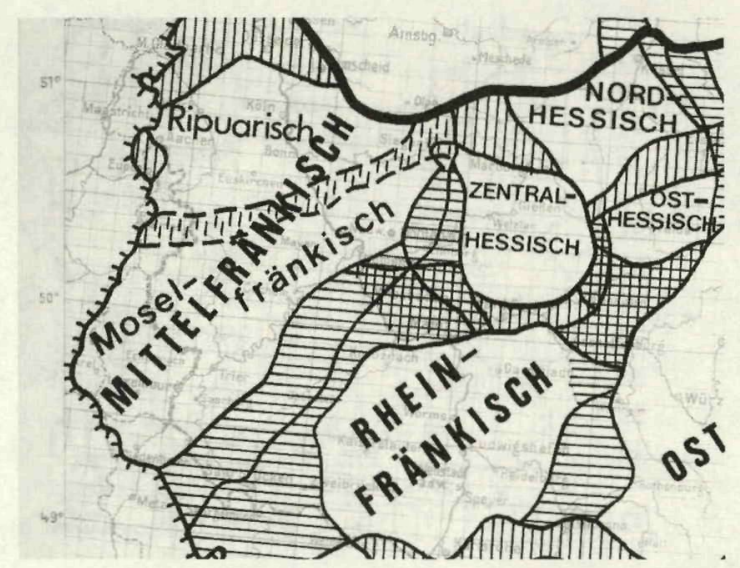

Figure 2. West Central German (Wiesinger 1983: 831)

(Ripuarisch) and Moselle Franconian (Moselfränkisch) dialect regions; Rhein Franconian (Rheinfränkisch); and a cluster of three Hessian dialect groups, namely Central, North, and East Hessian (Zentralhessisch, Nordhessisch, Osthessisch).

Niebaum \& Macha (2005: 217) consider Wiesinger's division, which is based on complex sets of phonological and morphological features, the closest to linguistic reality since it clearly indicates the existence of transitional zones. However, most overviews of the German dialect space (e.g. Beckers 1980) base their divisions on simpler isoglosses, resulting in a patchwork of dialect regions in which one area begins where another ends. The Institut für Deutsche Sprache (IDS), which maintains the dialect recordings that form the empirical basis for Dubenion-Smith $(2008,2010)$, organizes its database (Datenbank Gesprochenes Deutsch) according to such divisions. To facilitate the comparison of results from DubenionSmith (2008) to those in the present article, we therefore assume the simplified dialect division used by the IDS, as shown in Figure 3.

The WCG region (4) as a whole is demarcated by the heavy black line, and medium-heavy lines distinguish the subdivisions Ripuarian, Moselle Franconian, Hessian, and Pfälzisch, labeled a, b, c, and d, respectively. ${ }^{6}$

\footnotetext{
${ }^{6}$ Since no one-word equivalent for the German dialect designation Pfälzisch exists in English, we use the German term throughout the text. Note that Wiesinger (1983) uses the term Rheinfränkisch to refer to the area labeled Pfälzisch here and that the IDS division treats the Hessian dialect area as a single entity. We will return to Wiesinger's more linguistically accurate division of this linguistic space in section 4.3.3.
} 


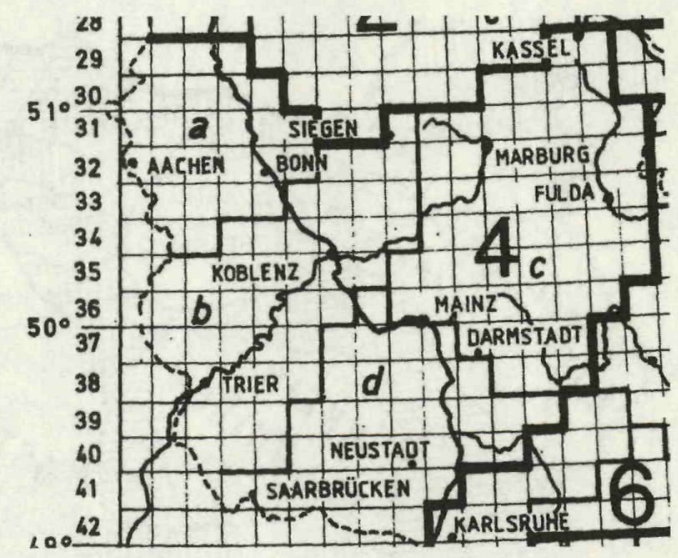

Figure 3. WCG dialect area (map from Haas \& Wagener 1992: 1611)

\section{Methodology}

\subsection{Consultants}

Fifty-five consultants (21 females and 34 males) tookpart in the questionnaire study. These consultants were recruited in each locality with the assistance of the local representative (Ortsvorsteher/in), whose cooperation was crucial in establishing contacts with members of the community who were suitable candidates for participation in the study. The following criteria, adapted from those used to select participants for the Mittelrheinischer Sprachatlas (see Bellmann 1994: 34-62), were used in recruiting the consultants. ${ }^{7}$

1. Second-generation residency (Ortsgebürtigkeit in zweiter Generation) The consultant and his/her parents are native to their place of residence. If this does not hold for both parents, then at least the mother is native to the locality.

2. Strong ties to place of residence (Ortsfestigkeit) The consultant has always lived in his/her place of origin without extended absences.

3. Limited mobility The consultant does/did not commute to his/her place of work.

\footnotetext{
${ }^{7}$ An important deviation from the criteria used for the Mittelrheinischer Sprachatlas (MrhSA) concerns mobility. While limited mobility was desired for all consultants in the present study, the consultants selected for Data Series II of the MrhSA were commuters. These consultants formed a group of younger speakers approximately 35 years in age.
} 
4. Manual occupation The consultant has/had a manual occupation (e.g. farmer, vintner, carpenter), if (formerly) employed.

5. Age The consultant is either approximately 35 or 75 years old.

These criteria were put into place to homogenize the sample groups (younger and older speakers) as much as practically possible so that any variation could be linked not to social variables but to the consultants' place of residency, that is, to a particular geographic location (see Cornips \& Poletto 2005: 946).

Since it is crucial that the elicited data be representative of the local dialect, a potential consultant's fulfillment of the first two criteria was a prerequisite for participation in the study. Command of dialect is not precluded by mobility or a non-manual occupation, so fulfillment of these two criteria was not mandatory for participation but strongly desirable. Indeed, requiring that they be met would have proven too restrictive in the search for younger consultants in particular, several of whom were employed in professional fields (e.g. secretary, architect) but who nonetheless spoke the local dialect. No relationship between word order and the fifth criterion, age, could be determined; this variable will therefore be left aside here (see Dubenion-Smith 2008: 154-156 for discussion). ${ }^{8}$

At the conclusion of data collection, four participants were excluded, leaving the data from 51 consultants for analysis. ${ }^{9}$

\subsection{Measuring points}

Interviews were conducted in 17 localities, distributed evenly across the WCG dialect area. The selection of measuring points targeted those with a population of less than 2,000 since community heads of smaller localities with closer contact to the local population would presumably have greater success in finding speakers of the local dialect. ${ }^{10}$ With one exception, this

\footnotetext{
${ }^{8}$ Note that gender is not included in the list of criteria; as Bellmann (1994: 52-54) notes, the connection between gender and command of dialect remains unclear.

${ }^{9}$ During the interview process, one consultant revealed that he had lived away from his place of origin for an extended period of time and thus did not fulfill the second criterion. Another consultant was the sole interviewee in a locality (Tünsdorf), making it impossible to determine the degree to which her responses were idiosyncratic. A third speaker was unable to complete the tasks in dialect, and the fourth was a clear outlier in his locality. $\mathrm{He}$ gave responses that diverged from those of the other three consultants' identical answers and unanimous metalinguistic statements about verb cluster word orders in the local dialect.

${ }^{10}$ Alexandra Lenz (p.c.) has also noted that, at least in the Moselle Franconian area, localities with populations of 2,000 and below tend to have similar social structures that differ from
} 
Table 1. Measuring points and locations by quadrant

\begin{tabular}{llc}
\hline Locality & Dialect Area & Quadrant \\
\hline Altenburg & $\mathrm{R}$ & 3102 \\
Alzheim & M & 3405 \\
Blankenbach & H & 3613 \\
Cappel & H & 3014 \\
Einselthum & P & 3809 \\
Elsbach & P & 3912 \\
Frankeneck & P & 4008 \\
Neuerburg/Bombogen & M & 3704 \\
Neukirchen & H & 3216 \\
Niederlauken & H & 3410 \\
Söven & $\mathrm{R}$ & 3206 \\
Strüth & P & 3608 \\
Tünsdorf & M & 3903 \\
Urexweiler & M & 4005 \\
Urft & R & 3303 \\
Wallroth & H & 3414 \\
Watzerath & M & 3502 \\
\hline
\end{tabular}

criterion was met, with populations ranging from 120 to $1,608 .{ }^{11}$ Three localities are situated in the Ripuarian dialect area, four in the Pfälzisch dialect area, and five in both the Moselle Franconian and Hessian dialect areas. Table 1 lists the name of each measuring point as well as the dialect region and quadrant in which it is located. The geographic distribution of these is indicated by the shaded squares in Figure 4.

\subsection{Instrument}

The research instrument designed for the present study was an interview questionnaire based on written questionnaires developed for the Syntaktischer Atlas der Deutschen Schweiz (SADS) and a pilot study of verb clusters in German, described in Seiler (2004) and Wurmbrand (2004), respectively. Although indirect methods of data elicitation, such as written questionnaires, are more cost- and time-efficient, direct methods includ-

those of localities with populations over 2,000 (see Lenz 2003).

"One locality, Urexweiler, has a population of 3,200 . This village was selected on the basis of personal contacts to dialect speakers. 


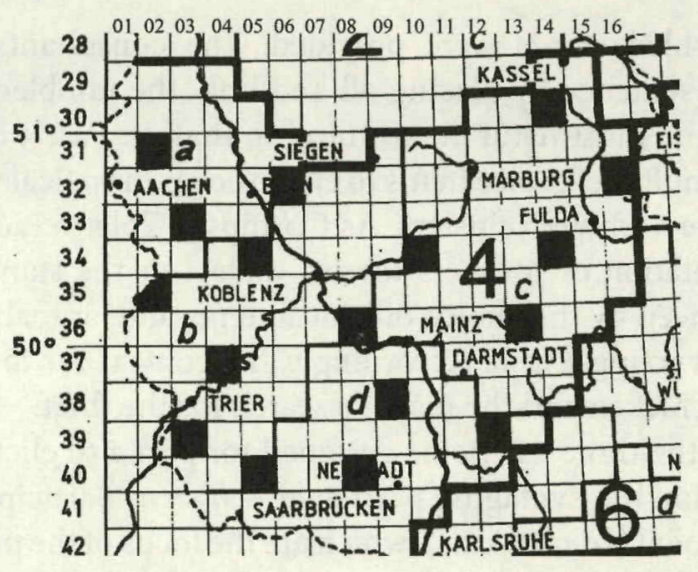

Figure 4. Geographic distribution of measuring points (map from Haas \& Wagener 1992: 1611)

ing the interview questionnaire are advantageous for a number of reasons, as Seiler (2010: 515-516) points out. ${ }^{12}$ Interference from the standard language in written tasks caused by unfamiliarity with writing in dialect can be avoided if consultants give their responses orally. The researcher also has the opportunity to clarify a task, make sure that the consultant is performing a task correctly, and check for and respond to possible testinternal inconsistencies. ${ }^{13}$ A questionnaire interview may be conducted, at least in part, as a 'think-aloud' task in which consultants are encouraged to make metalinguistic comments on their grammaticality judgments, allowing further insight into the phenomena in question (see Cornips \& Poletto 2005: 953).

The entire questionnaire consisted of three parts. Part 1 comprised a set of general background questions about the consultant's place of birth/ residence, language use, (former) occupation, place of work, and age. Part 2 was a sentence-completion task consisting of 10 items testing twoand three-verb clusters. ${ }^{14}$ For each item, the beginning of a sentence and a

\footnotetext{
${ }^{12}$ One anonymous reviewer has suggested that written questionnaires are, in fact, less cost-efficient than interviews. While the interviews themselves may be less costly, the costs involved in reaching the consultants in terms of travel time and expenses far outweigh those of administering written questionnaires by mail.

${ }^{13}$ For example, a consultant may give a particular response in one part of the questionnaire and not in another because a prompt or response choice has been misread.

${ }^{14}$ Although three-verb clusters were tested in the questionnaire study, the results for these will be treated separately.
} 
series of jumbled words were provided. The consultants' task was to complete the sentence by placing all and only the jumbled words in the order that came most naturally to mind in dialect. Part 3 consisted of 17 randomized multiple-choice items to elicit the grammatical word orders in two- and three-verb verb clusters. As Cornips \& Poletto (2005: 954) point out, the orientation of speakers toward dialect or the standard language can be influenced by the choice of lexical items and, arguably, the context used in constructing a task. Accordingly, the context for the task entailed the theft of a chicken and the mayor's search for the thief.

Below are the three test items designed for part 2 to elicit grammatical word orders for the syntagms participle + haben, participle + sein, and infinitive + modal (können 'can'), which are the focus of the present article: ${ }^{15}$

(2) Jemand hat Herrn Müller ein Huhn geklaut! Bürgermeister Schneider someone has Mr. Müller a chicken stolen mayor Schneider sucht das Huhn. Herr Schmidt, der Nachbar von Herrn Müller, ruft looks.for the chicken Mr. Schmidt the neighbor of Mr. Müller calls den Bürgermeister an ...

the mayor PART

[Er sagt, dass]

[hat/den Dieb/gesehen/er]

'Someone stole a chicken from Mr. Müller. Mayor Schneider is looking for the chicken. Mr. Schmidt, Mr. Müller's neighbor, calls the mayor ...' [He says that]

[has/the thief/seen/he]

(3) Herr Müller ist sauer; er will sein Huhn wiederhaben!

Mr. Müller is angry he wants his chicken have.back

[Er ist sauer, weil]

[zu ihm/ist/der Bürgermeister/früher/gekommen/nicht]

'Herr Müller is angry; he wants his chicken back!'

[He is angry because]

[to him/is/the mayor/earlier/come/not]

\footnotetext{
${ }^{15}$ While it has been shown that verb-cluster word order in varieties such as Central Bavarian is influenced by which modal occurs in the cluster (see Eroms 2005), no such influence could be identified for WCG on the basis of the Zwirner Corpus materials. Therefore, only one modal verb, können 'can', was tested in the questionnaire study.
} 
(4) Der Bürgermeister sucht weiter, findet aber nichts. the mayor looks further finds but nothing [Erglaubt, dass]

\section{[kann/nicht/das Huhn/finden/er]}

'The mayor keeps looking but doesn't find anything.'

[He believes that]

$$
\text { [can/not/the chicken/find/he] }
$$

In part 3, the three multiple-choice items used to test the two-verb syntagms are as follows:

(5) a. Herr Müller will wissen, ob der Bürgermeister das Huhn gefunden Mr. Müller wants know if the mayor the chicken found hat. has

b. Herr Müller will wissen, ob der Bürgermeister das Huhn hat ${ }_{1}$ gefunden ${ }_{2}$. 'Mr. Müller wants to know if the mayor has found the chicken.'

(6) a. Der Bürgermeister sagt, dass er gestern in die Stadt gefahren ${ }_{2}$ ist $_{1}$. the mayor says that he yesterday into the town gone ist

b. Der Bürgermeister sagt, dass er gestern in die Stadt ist gefahren $_{2}$. 'The mayor says that he went into town yesterday.'

(7) a. Er sagt, dass er das Huhn finden ${ }_{2}$ kann $_{1}$. he says that he the chicken find can

b. Er sagt, dass er das Huhn kann finden $_{2}$. 'He says that he can find the chicken.'

\subsection{Procedure}

The questionnaire was administered in an interview format. Apart from four interviews conducted at a local restaurant, each interview took place at the home of the consultant. After a brief introduction to the project, part 1 was conducted in Standard German. The consultants were then instructed to tell a children's story or describe a festival that takes place in the village in order to become accustomed to speaking dialect in front of the researcher. Part 2 began with the instructions to give natural responses to the stimuli, not limited to those that would be deemed correct in a formal setting. The consultants were asked to read the context sentences and the beginning of each test item as they would say them in dialect and then 
put the jumbled words into the correct order to complete the sentences, using dialect equivalents. In part 3 , the consultants first read each pair or group of sentences aloud, including those in examples (5)-(7), above, and rendered them word for word in the local dialect. ${ }^{16}$ Subsequently, they were directed to indicate the letter(s) of the sentence(s) in each group with an acceptable word order, and in the event that more than one sentence was acceptable, the letter of the sentence with the preferred word order. From this information, it was later possible to infer which word orders are obligatory and which ungrammatical. ${ }^{17}$

The consultants had a copy of the questionnaire from which to read the sentences but did not mark any responses themselves.

\subsection{Limitations}

While the design of the questionnaire proved successful overall, one difficulty arose repeatedly during the administration of the questionnaire. On the sentence-completion task, some consultants tended at first to produce two main clauses instead of a main clause followed by a subordinate clause with a cluster, although a subordinating conjunction was included in the beginning of each test item. After pointing this out to consultants and stressing the importance of using the conjunction in their answer, they were able to respond with a subordinate clause. However, it is clear that it was less natural for the consultants to produce a hypotactic structure (e.g. er sagt, dass er das Huhn finden kann 'he says that he can find the chicken') than a paratactic one (e.g. er sagt, er kann das Huhn finden 'he says he can find the chicken'). In future studies involving this type of task, moving the conjunction to the word jumble might help alleviate this problem. ${ }^{18}$

\footnotetext{
${ }^{16}$ In a pilot version of the questionnaire, the verbal elements of the prompts were presented in an approximation of dialect as a compromise between presenting all the words in Standard German as in Wurmbrand (2004), running the risk of interference, and presenting them all in dialect as in the SADS project, which avoids interference from the standard but can be confusing for dialect speakers from Germany unaccustomed to seeing their dialect in print. This approach proved ineffective in a pilot test and was abandoned for the final version of the questionnaire.

${ }^{17}$ If a consultant judged only one word order as acceptable during the interview, this was then taken to be the obligatory word order for that syntagm. Any word order not considered acceptable was taken to be ungrammatical.

${ }^{18}$ One anonymous reviewer has also suggested using matrix predicates that are incompatible with main clause complements, e.g. nicht wissen 'not know' and bedauern 'regret'.
} 
A second limitation deals with the procedure. Four consultants needed reminders to continue speaking in dialect after slipping into Standard German, primarily when reading the context sentences during the sentence-completion task. Although we could not identify any systematic differences between these consultants' responses and those of the other consultants in their respective localities, this is an undesirable task effect and may be related to the fact that the researcher was a speaker of the standard language. One solution to this problem might be to enlist the help of a native confederate at each measuring point, with the same social profile as the consultant, to conduct the interview completely in the local dialect. This approach has been successful, for example, in the elicitation of data for studies such as the Syntactische Atlas van de Nederlandse Dialecten (see Cornips \& Poletto 2005: 951) but seems feasible only for large-scale projects with substantial resources of time, money, and personnel.

\section{Results}

In this section, we first present the overall results of the sentence-completion and multiple-choice tasks, then turn to idiolectal and areal variation.

\subsection{Results of the sentence-completion and multiple-choice tasks}

The results of the sentence-completion task for the two-verb clusters are presented in Table 2. For each syntagm, the number of consultants who gave a particular word order is indicated in parentheses. As the data show, only the $2-1$ order, the sole grammatical order in Standard German, was produced spontaneously with the syntagms perfect with haben and sein. By contrast, both the $2-1$ and $1-2$ orders were elicited with infinitive + modal (INF + MOD).

Table 2. Responses to the sentence-completion task

\begin{tabular}{lll}
\hline Syntagms & Examples & Orders \\
perfect with haben & gesehen $_{2}$ hat $_{1}$ & $2-1(51 / 51)$ \\
perfect with sein & gekommen $_{2}$ ist $_{1}$ & $2-1(51 / 51)$ \\
INF + MOD & finden $_{2}$ kann $_{1}$ & $2-1(47 / 51)$ \\
& kann $_{1}$ finden $_{2}$ & $1-2(4 / 51)$ \\
\hline
\end{tabular}


Table 3. Aggregate responses to the multiple-choice task (in percent; $\mathrm{n}=51$ )

\begin{tabular}{|c|c|c|c|c|c|c|}
\hline Syntagms & Examples & Orders & 0 & $\mathbf{P}$ & A & $\mathrm{U}$ \\
\hline \multirow[t]{2}{*}{ Perfect with haben } & gefunden $_{2}$ hat $_{1}$ & $2-1$ & $\begin{array}{l}86.3 \\
(44)\end{array}$ & $\begin{array}{r}13.7 \\
(7)\end{array}$ & $\begin{array}{l}0.0 \\
(0)\end{array}$ & $\begin{array}{l}0.0 \\
\text { (o) }\end{array}$ \\
\hline & hat $_{1}$ gefunden $_{2}$ & $1-2$ & $\begin{array}{l}0.0 \\
(0)\end{array}$ & $\begin{array}{l}0.0 \\
(0)\end{array}$ & $\begin{array}{r}13.7 \\
(7)\end{array}$ & $\begin{array}{l}86.3 \\
(44)\end{array}$ \\
\hline \multirow[t]{2}{*}{ Perfect with sein } & gefahren $_{2}$ ist $_{1}$ & $2-1$ & $\begin{array}{l}86.3 \\
(44)\end{array}$ & $\begin{array}{r}13.7 \\
(7)\end{array}$ & $\begin{array}{l}0.0 \\
(0)\end{array}$ & $\begin{array}{l}0.0 \\
\text { (o) }\end{array}$ \\
\hline & ist $_{1}$ gefahren $_{2}$ & $1-2$ & $\begin{array}{l}0.0 \\
(0)\end{array}$ & $\begin{array}{l}0.0 \\
(0)\end{array}$ & $\begin{array}{r}13.7 \\
(7)\end{array}$ & $\begin{array}{l}86.3 \\
(44)\end{array}$ \\
\hline \multirow[t]{2}{*}{$\mathrm{INF}+\mathrm{MOD}$} & finden $_{2}$ kann $_{1}$ & $2-1$ & $\begin{array}{r}68.6 \\
(35)\end{array}$ & $\begin{array}{r}17.6 \\
(9)\end{array}$ & $\begin{array}{l}7.8 \\
(4)\end{array}$ & $\begin{array}{l}5.9 \\
(3)\end{array}$ \\
\hline & $\operatorname{kann}_{1}$ finden $_{2}$ & $1-2$ & $\begin{array}{l}5.9 \\
(3)\end{array}$ & $\begin{array}{l}7.8 \\
(4)\end{array}$ & $\begin{array}{r}17.6 \\
(9) \\
\end{array}$ & $\begin{array}{r}68.6 \\
(35) \\
\end{array}$ \\
\hline
\end{tabular}

Note: $\mathrm{O}=$ obligatory, $\mathrm{P}=$ preferred, $\mathrm{A}=$ acceptable, $\mathrm{U}=$ ungrammatical

Compared to the sentence-completion task, the multiple-choice task revealed greater variation. As Table 3 indicates, both the 2-1 and 1-2 orders were judged grammatical with all three two-verb syntagms tested. The results show that with the perfect constructions, only the $2-1$ order is either preferred or obligatory, while the $1-2$ order is neither preferred nor obligatory, and acceptable for just $13.7 \%$ of the consultants. However, both the 2-1 and 1-2 orders are acceptable, preferred, or obligatory with INF + MOD.

Comparing the results of the two tasks, the greater variation on the multiple-choice task is not unexpected. On the sentence-completion task, the consultants were only permitted to produce one word order, but on the multiple-choice task they were provided with both word orders and had to take each into consideration. Since, as Table 3 shows, the 1-2 order is not obligatory with the perfect constructions, we would not necessarily expect them to be produced spontaneously with this order. On the other hand, the 1-2 order is obligatory with INF + MOD for three speakers (5.9\%). Thus, we would expect the 1-2 order to be produced spontaneously by at least that many consultants on the sentence-completion task, which is the case. ${ }^{19}$

\footnotetext{
${ }^{19}$ Note also that the consultants did not give inconsistent answers. That is, if a consultant produced a particular word order on the sentence-completion task, he or she judged it a preferred or acceptable word order on the multiple-choice task as well.
} 


\subsection{Idiolectal variation}

While the results of the multiple-choice task provide aggregate data on the possible word orders according to syntagm and their relative degree of grammaticality, it is important to consider which word orders each individual speaker allows. ${ }^{20}$ The distribution of these is presented in Table 4.

Table 4. Number of speakers allowing either the $2-1$ or $1-2$ order or both, by syntagm

\begin{tabular}{llc}
\hline$(\mathrm{n}=5 \mathbf{1})$ & PTC + AUX & INF + MOD \\
\hline $2-1$ & 44 & 35 \\
$1-2$ & 0 & 3 \\
$2-1 / 1-2$ & 7 & 13 \\
\hline
\end{tabular}

Table 4 shows that the variation evidenced in Table 3 cannot be attributed only to interspeaker variation, that is, the categorical use of the $2-1$ order by some speakers and the 1-2 order by others. Rather, the consultants also display intraspeaker variation with 7 and 13 speakers using both word orders with PTC + AUX and INF + MOD, respectively. Note also that 1-2 does not emerge as a categorical word order with PTC + AUX.

A closer examination of this inter- und intraspeaker variation, taking both syntagms into account, reveals that 5 out of 9 theoretically possible grammars occur in the data according to the grammaticality of the 2-1 and 1-2 orders with each syntagm. These are presented in Table 5.

For the majority of speakers (31), the use of the $2-1$ order is categorical with both PTC + AUX and INF + MOD. Furthermore, the generalization emerges that the 1-2 order only co-occurs with the $2-1$ order with PTC + AUX, while the 1-2 order may occur alone with INF + MOD. In her overview of verb clusters in a variety of Continental West Germanic languages and dialects, Wurmbrand (2006: 237-238) notes that the 1-2 order occurs with PTC + AUX if and only if it occurs with INF + MOD. In the WCG data, seven speakers allow the 1-2 order with PTC + AUX, and for four of them this implicational hierarchy does not hold. Finally, INF + MOD displays more variation than PTC + AUX with respect to possible grammars (3 vs. 2) and the number of speakers who allow two word orders ( 13 vs. 7 ). This differ-

\footnotetext{
${ }^{20}$ For all consultants, the responses given for the perfect with haben were the same as those for the perfect with sein, so the syntagms are collapsed in the following as the syntagm participle + auxiliary (PTC + AUX).
} 
Table 5. Individual grammar combinations with PTC + AUX and INF + MOD

\begin{tabular}{|c|c|c|c|c|}
\hline \multirow[t]{2}{*}{$(n=51)$} & \multicolumn{2}{|c|}{ PTC + AUX } & \multicolumn{2}{|c|}{ INF + MOD } \\
\hline & $2-1$ & $1-2$ & $2-1$ & $1-2$ \\
\hline $\mathrm{n}=31$ & $\sqrt{ }$ & * & $\sqrt{ }$ & * \\
\hline $\mathrm{n}=10$ & $\sqrt{ }$ & * & $\sqrt{ }$ & $\sqrt{ }$ \\
\hline $\mathrm{n}=4$ & $\sqrt{ }$ & $\sqrt{ }$ & $\sqrt{ }$ & * \\
\hline $\mathrm{n}=3$ & $\sqrt{ }$ & * & * & $\sqrt{ }$ \\
\hline$n=3$ & $\sqrt{ }$ & $\sqrt{ }$ & $\sqrt{ }$ & $\sqrt{ }$ \\
\hline \multirow[t]{4}{*}{ Non-occurrence } & $\sqrt{ }$ & $\sqrt{ }$ & * & $\sqrt{ }$ \\
\hline & * & $\sqrt{ }$ & * & $\sqrt{ }$ \\
\hline & * & $\sqrt{ }$ & $\sqrt{ }$ & * \\
\hline & * & $\sqrt{ }$ & $\sqrt{ }$ & $\sqrt{ }$ \\
\hline
\end{tabular}

Note: $\sqrt{ }=$ grammatical; ${ }^{*}=$ ungrammatical

ence between syntagms is reflected in the slightly higher mean number of orders per speaker for INF + MOD (1.25) than for PTC + AUX (1.13), as displayed in Table 6.

Table 6. Number of accepted orders per speaker, by syntagm

\begin{tabular}{llcl}
\hline Cluster type & One order & Two orders & $\begin{array}{l}\text { Mean number of } \\
\text { orders per speaker }\end{array}$ \\
\hline PTC + AUX & $44(86.3 \%)$ & $7(13.7 \%)$ & $1.14(\mathrm{n}=51)$ \\
INF + MOD & $38(74.5 \%)$ & $13(25.5 \%)$ & $1.25(\mathrm{n}=51)$ \\
\hline
\end{tabular}

\subsubsection{Discussion}

As demonstrated in sections 4.1 and 4.2 , the $2-1$ and $1-2$ orders were judged grammatical on the multiple-choice task with both the syntagms PTC + AUX and INF + MOD, albeit with a difference in word-order variability linked to the morphosyntax of the cluster. In particular, the cluster involving an infinitive allows more variation than that involving a past participle. In light of these findings, two questions arise: (1) How does the distribution of word orders for PTC + AUX and INF + MOD in WCG compare to that in other languages?; and (2) How can the difference in word-order variability between PTC + AUX and INF + MOD be accounted for? 
Table 7. Attested word orders in two-verb clusters $\mathrm{PTC}+\mathrm{AUX}$ and INF + MOD

\begin{tabular}{lll}
\hline & PTC + AUX & INF + MOD \\
\hline Standard German & $2-1$ & $2-1$ \\
Afrikaans & $2-1$ & $1-2$ \\
Zurich Swiss German & $2-1$ & $2-1 / 1-2$ \\
Heerlen Dutch & $2-1 / 1-2$ & $2-1 / 1-2$ \\
West Central German & $2-1 / 1-2$ & $2-1 / 1-2$ \\
\hline
\end{tabular}

It is well known that the distribution of word orders in verb clusters, including those involving two verbs, is subject to considerable crosslinguistic variation. By way of illustration, Table 7 presents the attested word orders for five West Germanic languages and dialects. ${ }^{21}$

Wurmbrand (2006: 242-243), following Haegeman \& van Riemsdijk (1986), demonstrates that such variation can be captured from a theoretical perspective with parameters that govern the inversion of two sister nodes, resulting in different word orders among the elements in the verb cluster. These inversion rules specify the category of the inverting verbs (e.g. auxiliary, modal, infinitive, participle), the structure of the cluster with respect to branching and the node that dominates the inverting elements, and the optionality of inversion.

As Wurmbrand (2006: 244-249) illustrates, such inversion rules can capture microparametric variation in verb clusters, such as that illustrated in Table 7 , independent of whether one assumes a basic head-initial (1-2) or head-final (2-1) word order. For example, if one assumes a head-final base according to which the 1-2 order is derived through movement, the difference between Afrikaans and Zurich Swiss German in grammatical word orders can be attributed to rules that, when the head is a modal verb, make the inversion of the head and its verbal complement obligatory in Afrikaans and optional in Zurich Swiss German. However, as Wurmbrand (2006: 285) points out, a major weakness of this and other approaches (see Wurmbrand 2006: 286-294) is that the rules formulated to account for the distribution of word orders in verb clusters are often no more than stipulated parameters that offer only a formal description of the word-order facts and do not derive from independent grammatical principles.

\footnotetext{
${ }^{21}$ These data were taken from the following sources: Lötscher (1978) (Zurich Swiss German), Wurmbrand (2006: 237) (Standard German, Afrikaans), and Cornips (2009) (Heerlen Dutch).
} 
One model that holds promise for capturing variation in verb clusters is Optimality Theory (see Prince \& Smolensky 2004). In this model, multiple competing output candidates (here: verb serializations) are evaluated against a hierarchy of universal and violable well-formedness constraints. ${ }^{22}$ The 'winner' is the output that incurs the fewest violations of the highestranking constraint that distinguishes the candidates. In his study of verb cluster variation in Swiss German dialects, Seiler (2004: 385-391) proposes various rankings of six constraints to account for six distinct grammars attested across the dialect space involving four syntagms (PTC + AUX, INF + MOD, lexical verb + lexical verb, lexical verb + MOD + AUX). By using both ranked and tied constraints, Seiler can differentiate, for example, one grammar in which the 1-2 order is grammatical and the $2-1$ order is ungrammatical with the syntagm INF + MOD, and another grammar in which both the 1-2 and 2-1 word orders are grammatical. Because Seiler deals with both the syntagms PTC + AUX and INF + MOD, his analysis could be readily adopted to explain the cross-linguistic variability in word orders evidenced in Table 7.

However, even in cases in which two languages share that same wordorder inventory for two-verb clusters, there are finer-grained differences that must be taken into consideration. In particular, languages may vary with respect to directionality preference (i.e. whether the $2-1$ or $1-2$ order is preferred as a single order if both are grammatical) and also to differences in intraspeaker variability (i.e. whether speakers allow one or both orders). For example, Table 7 , above, shows that in both Heerlen Dutch, a regional standard spoken in the southeastern Netherlands, and WCG, the 2-1 and 1-2 orders are grammatical with both the syntagms PTC + AUX and INF + MOD. Yet on the basis of the recorded spontaneous speech of 67 speakers, Cornips (2009: 210-211) demonstrates for Heerlen Dutch that 2-1 is preferred as a single word order with participial clusters, while 1-2 is the preferred single word order with infinitival clusters ${ }^{23}$ and that participial clusters display more individual variety than infinitival clusters ( $51 / 67 \mathrm{vs}$. $13 / 67$ speakers produce both the 2-1 and 1-2 orders with these two cluster types, respectively). ${ }^{24}$

${ }^{22}$ The notion of universal constraints is not uncontroversial (see e.g. Mohanan \& Mohanan 2003).

${ }^{23}$ Cornips (2009) considers two types of clusters: those consisting of a participle and a perfective or passive auxiliary, and those involving an infinitive and a modal or aspectual verb. We therefore use the terms 'participial cluster' and 'infinitival cluster' when referring to the Heerlen Dutch data.

${ }^{24}$ While Cornips (2009: 211) states that the modal/aspectual (infinitival) clusters prefer 1-2 
In WCG, by contrast, only the $2-1$ order occurs categorically with the participial cluster PTC + AUX, and 2-1 is preferred as a single order with the infinitival cluster INF + MOD. Furthermore, the latter syntagm displays more individual variety than the former, as Tables $4-6$, above, show.

It is important to recognize that these word-order patterns in Heerlen Dutch and WCG as a whole reflect a composite of multiple grammars associated with individual speakers. Therefore, to explain, for example, why the participial cluster displays more variability than the infinitival cluster in Heerlen Dutch, but why the opposite is the case for WCG, it is necessary to account for differences between the languages at the individual level.

Barbiers (2005), an investigation of three-verb clusters in the Dutch language area, provides a framework within which such differences can be understood. Barbiers argues that the attested variation can be attributed to language-internal principles of generative grammar on the one hand and to sociolinguistic factors on the other. On Barbiers's account, grammatical principles rule out the 2-1-3 order, one of six logically possible orders with three-verb clusters, and restrict the $2-3-1$ and $3-1-2$ orders to particular syntagms. According to Barbiers, all dialects in this area have the same grammatical system as far as three-verb clusters are concerned, but the word orders that speakers realize vary according to the sociolinguistic factors, in particular to which word orders occur in the input from a speaker's environment. Barbiers's hypothesis can explain the fact that more word orders are allowed in the transitional zones between dialect areas than in the areas proper: Because individual speakers hear more orders in the transitional zones than elsewhere, more orders are reported there.

Returning now to two-verb clusters in Heerlen Dutch and WCG, the cross-linguistic differences in directionality preference and intraspeaker variability discussed above may be explained in the spirit of Barbiers's (2005) approach. We propose that while both dialect spaces share the same word-order inventory at the level of the language/dialect, that is, the 2-1 and 1-2 orders are grammatical with both the participial and infinitival clusters in each area as a whole, the differences can be linked to the input that individual speakers receive, which leads to different grammatical

as the single order and the accompanying Figure 2 shows that one speaker produces only 2-1 as the single order, an earlier description of the data (pp. 209-210) indicates that the 2-1 order is not used categorically with these clusters. Despite this discrepancy, however, the contrast described in the main text of the present article between the infinitival and participial clusters in Heerlen Dutch remains clear. 
patterns at the individual level. ${ }^{25}$ In the Heerlen Dutch area, speakers primarily hear 2-1 as a single order with participial clusters but the $1-2$ order with infinitival clusters, ${ }^{26}$ while in the WCG area, speakers hear only the 2-1 order as a single order with PTC + AUX and primarily the $2-1$ order with INF + MOD. Furthermore, speakers of Heerlen Dutch hear two orders with participial clusters more often than with infinitival clusters, whereas the opposite is the case for speakers of WCG. In this way, these differences between Heerlen Dutch and WCG as well as the difference in word-order variability between PTC + AUX and INF + MOD in WCG can be explained. This approach could be taken to account for other cases in which multiple languages share the same word-order inventory for verb clusters but display different fine-grained patterns of inter- and intraspeaker variation.

\subsection{Areal variation}

The focus of sections 4.1 and 4.2 was the patterns of idiolectal variation with two-verb clusters in WCG and an explanation for the difference between the syntagms PTC + AUX and INF + MOD in directionality preference and intraspeaker variability from a theoretical and cross-linguistic perspective. In this section, we examine the results of the questionnaire study from a geographic perspective to determine what areal variation exists in WCG and how this variation compares to that evidenced in a corpus study of verbal complexes in WCG, Dubenion-Smith (2008).

\subsubsection{Areal variation: dialect areas, questionnaire study}

Let us first consider the two larger areas into which the WCG dialect area may be subdivided, namely Central Franconian and Rhine Franconian. The results of the multiple-choice task are presented in Table $8 .{ }^{27}$

\footnotetext{
${ }^{25}$ We make no claim that the shared word-order inventory is attributable to geographic continuity between the Heerlen Dutch and WCG areas. Furthermore, while we treat each word-order combination in Table 5 as a separate grammar, these would be considered different subset realizations of a single underlying grammar according to Barbiers (2005).

${ }^{26}$ As pointed out in note 24, it is possible that speakers of Heerlen Dutch hear only the 1-2 order as a single order with infinitival clusters.

${ }^{27}$ To avoid idiosyncratic responses, only those word orders given by at least two consultants in a locality have been counted. In several cases this has led in Tables 8 and 9 to the number of speakers' responses for a given syntagm and word order to be one fewer than the total number of speakers for that dialect region.
} 


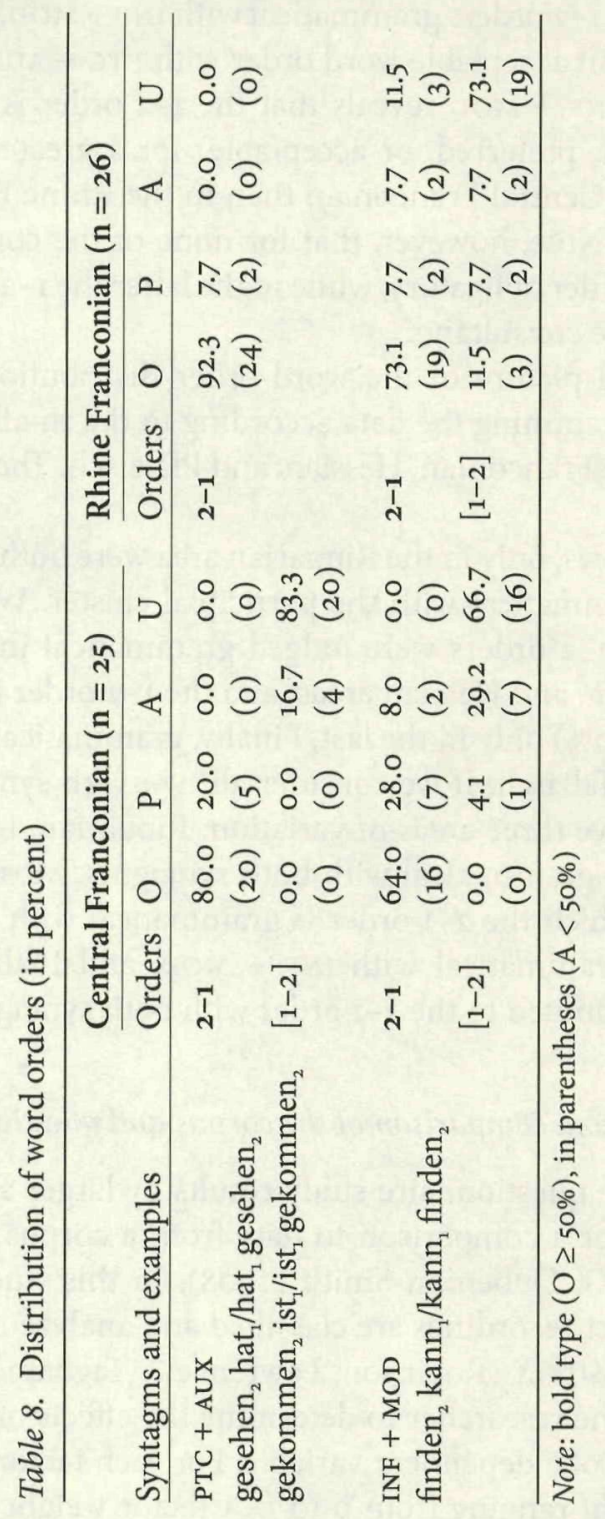


The data show that overall, Central Franconian displays greater variation than Rhine Franconian. While the consultants in both regions judged the 2-1 and 1-2 orders grammatical with INF + MOD, only in Central Franconian is 1-2 an acceptable word order with PTC + AUX. A closer look at the results for INF + MOD reveals that the $1-2$ order is also grammatical (i.e. obligatory, preferred, or acceptable) for a greater percentage of consultants in the Central Franconian than in the Rhine Franconian area (33.3\% vs. $26.9 \%)$. Note, however, that for none of the consultants in the former is the 1-2 order obligatory, while in the latter the 1-2 order is obligatory for $11.5 \%$ of the consultants.

A finer-grained picture of the word-order distribution in the WCG area emerges by examining the data according to the smaller dialect areas Ripuarian, Moselle Franconian, Hessian, and Pfälzisch. The results are presented in Table 9.

As the table shows, only in the Ripuarian area were both the 2-1 and 1-2 orders judged grammatical with the participial cluster. With INF + MOD, both the $2-1$ and $1-2$ orders were judged grammatical in the Ripuarian, Moselle Franconian, and Hessian areas, and the 1-2 order is obligatory for some speakers $(23.1 \%)$ only in the last. Finally, grammaticality is limited to the 2-1 order in Pfälzisch. If we consider all two-verb syntagms together, we can thus observe three areas of variation: Ripuarian, in which the 2-1 and 1-2 orders are grammatical with both syntagms, Moselle Franconian and Hessian, in which the $2-1$ order is grammatical with PTC + AUX and both orders are grammatical with INF + MOD, and Pfälzisch, in which grammaticality is limited to the $2-1$ order with both syntagms.

\subsubsection{Areal variation: comparison of the corpus and questionnaire studies}

The analysis of the questionnaire study results by larger and smaller dialect areas allows for a comparison to data from a corpus study of verbal complexes in WCG, Dubenion-Smith (2008). In this study, verbal complexes in 187 dialect recordings are classified and analyzed with the statistics package GoldVarb X (Robinson, Lawrence \& Tagliamonte 2001). This program enables the researcher to determine the effects of various factors on the occurrence of a dependent variable. For each factor, GoldVarb outputs a factor weight ranging from o to 1 . A factor weight of 0.5 indicates that the factor neither favors nor disfavors the occurrence of the dependent variable, in this case the 1-2 order, while values above and below 0.5 


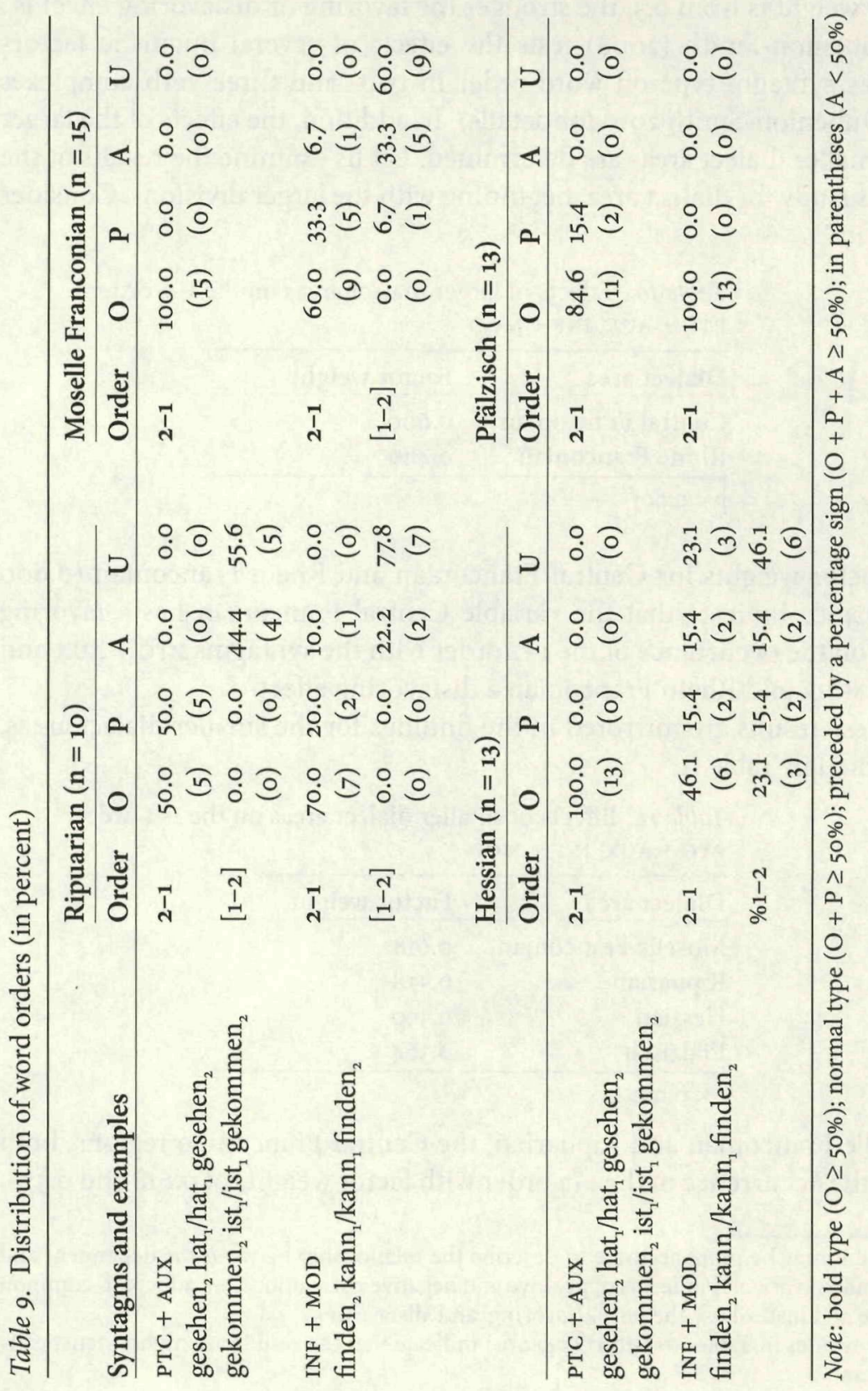


indicate a favoring and disfavoring effect, respectively. ${ }^{28}$ The farther away a factor weight is from 0.5, the stronger the favoring or disfavoring effect is.

Dubenion-Smith (2008) tests the effects of several linguistic factors such as syntagm type on word order in two- and three-verb complexes (see Dubenion-Smith 2010 for details). In addition, the effects of the larger and smaller dialect areas are determined. Let us examine the results of the corpus study for dialect area, beginning with the larger divisions. Consider Table $10 .{ }^{29}$

Table 10. Effects of larger dialect areas on the 1-2 order:

PTC + AUX, INF + MOD

\begin{tabular}{ll}
\hline Dialect area & Factor weight \\
\hline Central Franconian & 0.600 \\
Rhine Franconian & 0.440 \\
\hline$p<0.001$ &
\end{tabular}

The factor weights for Central Franconian and Rhein Franconian ( 0.600 and 0.440 ) indicate that the variable Central Franconian has a favoring effect on the occurrence of the 1-2 order with the syntagms PTC + AUX and INF + MOD, and Rhein Franconian a disfavoring effect.

These results are mirrored in the findings for the smaller dialect areas, presented in Table 11.

Table 11. Effects of smaller dialect areas on the 1-2 order: $\mathrm{PTC}+\mathrm{AUX}, \mathrm{INF}+\mathrm{MOD}$

\begin{tabular}{ll}
\hline Dialect area & Factor weight \\
\hline Moselle Franconian & 0.618 \\
Ripuarian & 0.578 \\
Hessian & 0.520 \\
Pfälzisch & 0.364 \\
\hline
\end{tabular}

$p<0.001$

Moselle Franconian and Ripuarian, the Central Franconian regions, both favor the occurrence of the 1-2 order with factor weights of 0.618 and 0.578 ,

\footnotetext{
${ }^{28}$ While it may be more accurate to describe the relationship between the dependent and independent variables in terms of positive and negative correlations, we adhere to common practice and instead use the terms 'favoring' and 'disfavoring'.

${ }^{29}$ The $p$-values in Tables 10 and $11(<0.001)$ indicate that the results are highly statistically significant.
} 
respectively. As for the Rhine Franconian regions, on the other hand, the factor weights of 0.520 and 0.364 indicate that Hessian only marginally favors and Pfälzisch disfavors the occurrence of the 1-2 order.

Let us compare the results of the corpus and questionnaire studies, starting with the larger dialect areas Central Franconian and Rhine Franconian. Like the corpus study, which indicates a favoring effect of Central Franconian and a disfavoring effect of Rhine Franconian on the occurrence of the 1-2 order, the results of the questionnaire study point to a greater prevalence of the 1-2 order in Central Franconian than in Rhine Franconian, as it occurs with both PTC + AUX and INF + MOD only in the former.

As for the smaller dialect areas, the (marginally) favoring effects of Moselle Franconian, Ripuarian, and Hessian and the disfavoring effect of Pfälzisch on the occurrence of the 1-2 order in the corpus study are reflected in the questionnaire study in the presence of this order in Ripuarian, Moselle Franconian, and Hessian with INF + MOD alone or both PTC + AUX and INF + MOD, and the absence thereof in Pfälzisch.

These similarities suggest that as far as two-verb clusters are concerned, the relative distribution in word orders across the WCG dialect space has remained stable over the roughly 50 years that separate the field work completed for the Zwirner Corpus and data collection for the questionnaire study. ${ }^{30}$

\subsubsection{Areal variation: localities}

Finally, we consider each locality separately to round out our investigation of areal variation. The distribution of word orders by locality for the twoverb syntagms is summarized in Table 12.

If degree of preference is taken into account (i.e. $1-2 / 2-1$ vs. $2-1 / 1-2$ ), then five grammars emerge from the data. ${ }^{31}$ As Figure 5 shows, the occur-

\footnotetext{
${ }^{30}$ Note that while the relative areal distribution of word orders appears to have remained stable, this does not imply that the overall usage of the 1-2 order has not declined over time, at least in parts of the WCG dialect region. For example, while the Pfälzisch area disfavors the occurrence of the 1-2 order in the corpus study, the factor weight above o indicates that this word order is still attested. This stands in contrast to the apparent absence of the 1-2 order in this region according to the recent questionnaire study.

${ }^{31}$ The distinction between grammars 2 and 3 is not based on differences in production frequency between the $2-1$ and 1-2 orders with the syntagm INF + MOD. Rather, there is a robust difference in preference for one or the other word order that should be taken into account (see Seiler 2004: 383).
} 
Table 12. Distribution of word orders in the two-verb syntagms by locality

\begin{tabular}{llll}
\hline Locality & PTC + AUX & INF + MOD & Grammar \\
\hline Altenburg & $2-1$ & $2-1$ & 1 \\
Blankenbach & $2-1$ & $2-1$ & 1 \\
Einselthum & $2-1$ & $2-1$ & 1 \\
Elsbach & $2-1$ & $2-1$ & 1 \\
Frankeneck & $2-1$ & $2-1$ & 1 \\
Neuerburg/Bombogen & $2-1$ & $2-1$ & 1 \\
Niederlauken & $2-1$ & $2-1$ & 1 \\
Strüth & $2-1$ & $2-1$ & 1 \\
Urexweiler & $2-1$ & $2-1$ & 1 \\
Urft & $2-1$ & $2-1$ & 1 \\
Alzheim & $2-1$ & $2-1 / 1-2$ & 2 \\
Cappel & $2-1$ & $2-1 / 1-2$ & 2 \\
Watzerath & $2-1$ & $2-1 / 1-2$ & 2 \\
Neukirchen & $2-1$ & $1-2 / 2-1$ & 3 \\
Wallroth & $2-1$ & $1-2$ & 4 \\
Söven & $2-1 / 1-2$ & $2-1 / 1-2$ & 5 \\
\hline
\end{tabular}

Note: The word orders are supersets of the grammars in a locality, that is to say that not all speakers may produce all the possible word orders. As in the previous section, only word orders provided by at least two speakers in each locality have been taken into consideration.

rence of these grammars does not correspond to any clear geographic continuum across the entire WCG dialect area. ${ }^{32}$ Note, however, that four out of five grammars occur in the Hessian dialect area. Recall from section 2 that Wiesinger (1983) subdivides this dialect space into three smaller regions: Central Hessian (Zentralhessisch), North Hessian (Nordhessisch), and East Hessian (Osthessisch). If we consider only those localities situated squarely in one of these regions, Niederlauken-A (Central Hessian), Cappel-B (North Hessian), and Neukirchen-C (East Hessian), then a clear correspondence between grammar and geography emerges, shown in Figure 6 (see p. [28]).This correspondence is interesting in that the distribution of the syntactic variable correlates to a dialect division based primarily on

${ }^{32}$ As Jürg Fleischer (p.c.) has pointed out, grammar 1, which corresponds to the pattern in Standard German, predominates in the south in which large cities such as Frankfurt and Mainz are located. It is possible that this word order has spread out slowly but not yet reached peripheral areas. Still, the fact remains that grammar 1 is also to be found in the Ripuarian area and that localities with grammar 2 do not form a cohesive unit. 


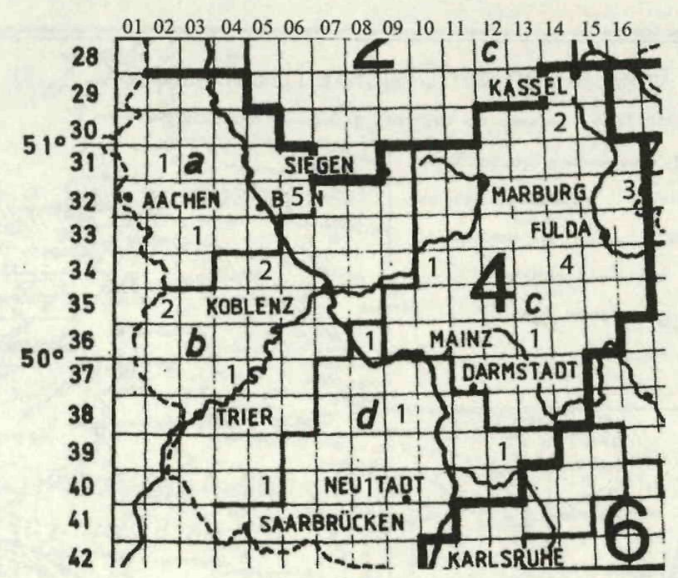

Figure 5. Distribution of grammars: two-verb syntagms (map from Haas \& Wagener 1992: 1611)

phonological features. Furthermore, in light of the fact that dialect syntactic features generally vary over larger geographic regions than phonological ones (see Kortmann 2010: 842, 846), this result is perhaps unexpected since we are dealing here with a relatively small geographic area.

Given the variation evidenced with the two-verb syntagms in the Hessian dialect area, a closer investigation of word-order phenomena in this region should prove a particularly fruitful area for further research.

\section{Summary}

The goal of this article was to discuss idiolectal and areal variation in twoverb clusters in WCG. A questionnaire consisting of sentence-completion and multiple-choice tasks, which was administered to 55 dialect speakers from 17 localities across the WCG dialect area, formed the empirical basis for the study.

Beginning with idiolectal variation, the sentence-completion task displayed less variation than the multiple-choice task overall. The sentencecompletion task yielded only the (standard) $2-1$ order with PTC + AUX and the $2-1$ and $1-2$ orders with INF + MOD, while both the $2-1$ and $1-2$ orders were judged grammatical with each syntagm on the multiple-choice task. Both syntagms displayed inter- and intraspeaker variation, and taken together, five separate grammars could be identified. Furthermore, it was 


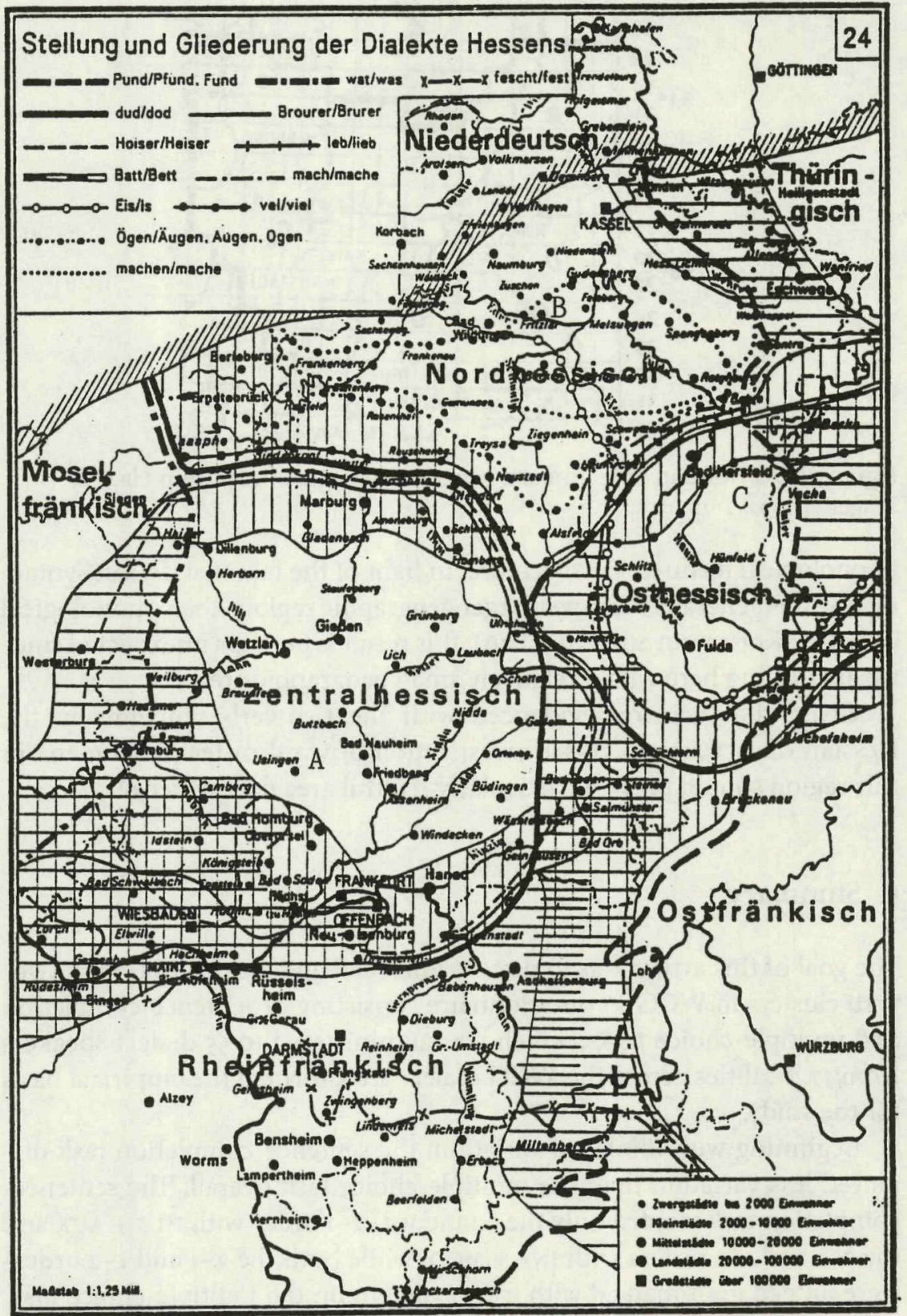

Figure 6. Distribution of grammars 1, 2, and 3 (map from Wiesinger 1980) 
shown that INF + MOD displays more individual variation than PTC + AUX. In light of the fact that Heerlen Dutch shows the opposite pattern, this finding was attributed to differences in the speakers' input from the linguistic environment, following Barbiers's (2005) analysis of three-verb clusters in the Dutch language area.

As for areal variation, the questionnaire study revealed more wordorder variability in Central Franconian than in Rhine Franconian. The results for the smaller dialect regions Ripuarian, Moselle Franconian, Hessian, and Pfälzisch reflected this difference as well, with the most variation in the Ripuarian area and the least in the Pfälzisch area. These results were compared to a recent corpus study of verbal complexes in WCG. It was determined that the corpus data display a similar distribution of wordorder frequencies. Given that the data for the two studies were collected approximately 50 years apart, it was concluded that the relative areal distribution of word orders has remained stable as far as two-verb clusters are concerned. Finally, word order was examined at the locality level. Five grammars emerged, which are not distributed across the WCG dialect area on a clear continuum. However, the Hessian area displays greater variation than the other three dialect areas, with different grammars associated with the three sub-regions Central, North, and East Hessian. Given this variability, the Hessian dialect area is a promising locus of future research. Indeed, with a relatively small number of measuring points, this study should be considered but a starting point for further investigations of verbal complexes in the modern WCG dialects. It is our hope that the results of the study will inspire new in-depth fieldwork on this topic.

\section{References}

ASIt - Atlante Sintattico d'Italia. Scientific coordinator: Paola Benincà. http://asiscnr.unipd.it/index.html.

Auer, Peter \& Jürgen Erich Schmidt, eds. 2010. Language and space: An international handbook of linguistic variation. Vol. 1: Theories and methods. Berlin \& New York: Mouton de Gruyter.

Barbiers, Sjef. 2005. Theoretical restrictions on word order variation in three-verb clusters. In Leonie Cornips \& Karen P. Corrigan, eds. Syntax and variation: Reconciling the biological with the social. Amsterdam: John Benjamins, 233264. 
Barbiers, Sjef, Leonie Cornips \& Susanne van der Kleij, eds. 2002. Syntactic microvariation. Electronic publication of the Meertens Instituut. hwww.meertens. knaw.nl/projecten/sand/ synmic.

Beckers, Hartmut. 1980. Westmitteldeutsch. In Hans Peter Althaus, Helmut Henne \& Herbert Ernst Wiegand, eds. Lexikon der germanistischen Linguistik, vol. 3. Tübingen: Max Niemeyer, 468-474.

Bellmann, Günter. 1994. Einführung in den Mittelrheinischen Sprachatlas. Tübingen: Max Niemeyer.

Benincà, Paola, ed. 1989. Dialect variation and the theory of grammar. Dordrecht: Foris Publications.

Besten, Hans den \& Jerold A. Edmondson. 1983. The verbal complex in Continental West Germanic. In Werner Abraham, ed. On the formal syntax of the Westgermania. Amsterdam: John Benjamins, 155-216.

Black, James \& Virginia Motapanyane, eds. 1996. Microparametric syntax and dialect variation. Amsterdam: John Benjamins.

Cornips, Leonie. 2009. Empirical syntax: Idiolectal variability in two- and threeverb clusters in regional standard Dutch and Dutch dialects. In Andreas Dufter, Jürg Fleischer \& Guido Seiler, eds. Describing and modeling variation in grammar. Berlin \& New York: Mouton de Gruyter, 203-224.

Cornips, Leonie \& Cecilia Poletto. 2005. On standardising syntactic elicitation techniques. Lingua 115: 939-957.

D’Alessandra, Roberta, Adam Ledgeway \& Ian G. Roberts, eds. 2010. Syntactic variation: The dialects of Italy. Cambridge \& New York: Cambridge University Press.

Dubenion-Smith, Shannon A. 2008. Verbal complex phenomena in the West Central German dialects. Madison: University of Wisconsin-Madison doctoral dissertation.

Dubenion-Smith, Shannon A. 2010. Verbal complexes in West Central German: Empirical domain and multi-causal account. Journal of Germanic Linguistics 22: 99-191.

Dubenion-Smith, Shannon A. 2011. Verbalkomplexe im Schlesischen. Zeitschrift für Dialektologie und Linguistik 78: 281-320.

Eroms, Hans-Werner. 2005. Wortstellung bei Modalverbkonstruktionen im Mittelbairischen. In Ulrich Kanz \& Alfred Wildfeuer, eds. Kreuther Kräuterbuschen: Beiträge zur 9. Bayerisch-österreichischen Dialektologentagung in Wildbad Kreuth, September 2004. Regensburg: Edition Vulpes, 151-169.

Fleischer, Jürg. 2002. Die Syntax von Pronominaladverbien in den Dialekten des Deutschen. Eine Untersuchung $z u$ Preposition Stranding und verwandten Phänomenen. Wiesbaden: F. Steiner. (= Zeitschrift für Dialektologie und Linguistik. Beihefte 123).

Haas, Walter \& Peter Wagener, eds. 1992. Gesamtkatalog der Tonaufnahmen des 
Deutschen Spracharchivs. Tübingen: Max Niemeyer. (= Phonai 38/39).

Haegeman, Liliane. 1992. Theory and description in generative syntax: A case study in West Flemish. Cambridge: Cambridge University Press.

Haegeman, Liliane \& Henk van Riemsdijk. 1986. Verb projection raising, scope, and the typology of rules affecting verbs. Linguistic Inquiry 17: 417-466.

Kaufmann, Göz. 2007. The verb cluster in Mennonite Low German: A new approach to an old topic. Linguistische Berichte 210: 147-207.

Kiss, Katalin É. \& Henk van Riemsdijk, eds. 2004. Verb clusters: A study of Hungarian, German, and Dutch. Amsterdam: John Benjamins.

Koopman, Hilda \& Anna Szabolcsi. 2000. Verbal complexes. Cambridge, MA: MIT Press.

Kortmann, Bernd. 2010. Areal variation in syntax. In Auer \& Schmidt, eds. 837864.

Krogh, Steffen. 2008. Die Wortstellung der Verbalfelder im Ostjiddischen. Zeitschrift für Dialektologie und Linguistik 75: 21-60.

Lenz, Alexandra. 2003. Struktur und Dynamik des Substandards. Eine Studie zum Westmitteldeutschen (Wittlich/Eifel). Stuttgart: Steiner.

Lötscher, Andreas. 1978. Zur Verbstellung im Zürichdeutschen und in anderen Varianten des Deutschen. Zeitschrift für Dialektologie und Linguistik 45: 1-29.

Louden, Mark L. 2011. Synchrony and diachrony of verb clusters in Pennsylvania Dutch. In Michael T. Putman, ed. Studies on German-language islands. Amsterdam: John Benjamins, 165-186.

Mohanan, K. P. \& Tara Mohanan. 2003. Universal and language particular constraints in OT-LFG. In Miriam Butt \& Tracy Holloway King, eds. Proceedings of the LFG03 conference. Stanford, CA: CSLI Publications, 290-306.

Niebaum, Hermann \& Jürgen Macha. 2005. Einführung in die Dialektologie des Deutschen. 2nd edn. Tübingen: Max Niemeyer.

Nübling, Damaris. 1992. Klitika im Deutschen. Schriftsprache, Umgangssprache, alemannische Dialekte. Tübingen: G. Narr. (= ScriptOralia 42).

Patocka, Franz. 1997. Satzgliedstellung in den bairischen Dialekten Österreichs. Frankfurt am Main: Peter Lang.

Penner, Zvi, ed. 1995. Topics in Swiss syntax. Bern \& New York: Peter Lang.

Prince, Alan \& Paul Smolensky. 2004. Optimality theory: Constraint interaction in generative grammar. Malden, MA: Blackwell.

Robinson, John, Helen Lawrence \& Sali Tagliamonte. 2001. GoldVarb 2001: A multivariate analysis application for Windows. www.york.ac.uk/depts/lang/webstuff/ goldvarb.

SADS - Syntaktischer Atlas der deutschen Schweiz. University of Zurich, Department of German. Project director: Elvira Glaser. www.ds.uzh.ch/dialektsyntax/ index.html.

SAND - Syntactische Atlas van de Nederlandse Dialecten, vol. 2. Sjef Barbiers, 
Johan van der Auwera, Hans Bennis, Eefje Boef, Gunther De Vogelaer \& Margreet van der Ham, eds. 2009. Amsterdam: Amsterdam University Press.

SyHD - Syntax hessischer Dialekte. Deutscher Sprachatlas, University of Marburg. Project directors: Jürg Fleischer, Alexandra Lenz, Helmut Weiß. www.syhd. info.

Schmid, Tanja \& Ralf Vogel. 2004. Dialectal variation in German 3-verb clusters: A surface oriented Optimality Theoretic account. Journal of Comparative Germanic Linguistics 7: 235-274.

Schönenberger, Manuela. 1995. Constituent order in the VP: Verb raising and verb projection raising. In Penner, ed. 347-411.

Seiler, Guido. 2003. Präpositionale Dativmarkierung im Oberdeutschen. Wiesbaden: F. Steiner. (= Zeitschrift für Dialektologie und Linguistik. Beihefte 124).

Seiler, Guido. 2004. On three types of dialect variation and their implications for linguistic theory: Evidence from verb clusters in Swiss German dialects. In Bert Kortmann, ed. Dialectology meets typology: Dialect grammar from a crosslinguistic perspective. Berlin \& New York: Mouton de Gruyter, 367-399.

Seiler, Guido. 2010. Investigating language in space: Questionnaire and interview. In Auer \& Schmidt, eds. 512-527.

Sutter, Gert de. 2007. Naar een corpusgebaseerde, cognitief-functionele verklaring van de woordvolgordevariatie in tweeledige werkwoordelijke eindgroepen. Nederlandse Taalkunde 12: 302-330.

Tortora, Christina, ed. 2002. The syntax of Italian dialects. New York: Oxford University Press.

Weiß, Helmut. 1998. Syntax des Bairischen: Studien zur Grammatik einer natürlichen Sprache. Tübingen: Max Niemeyer.

Wiesinger, Peter. 1980. Die Stellung der Dialekte Hessens im Mitteldeutschen. In Reiner Hildebrant \& Hans Friebertshäuser, eds. Sprache und Brauchtum: Bernhard Martin zum 90. Geburtstag. Marburg: Elwert.

Wiesinger, Peter. 1983. Die Einteilung der deutschen Dialekte. In Werner Besch et al., eds. Dialektologie: Ein Handbuch zur deutschen und allgemeinen Dialektforschung. 2. Halbband. Berlin \& New York: Walter de Gruyter, 807-900.

Wurmbrand, Susanne. 2004. West Germanic verb clusters: The empirical domain. In Katalin É. Kiss \& Henk van Riemsdijk, eds. Verb clusters: A study of Hungarian, German, and Dutch. Amsterdam: John Benjamins, 43-85.

Wurmbrand, Susanne. 2006. Verb clusters, verb raising, and restructuring. In Martin Everaert \& Henk van Riemsdijk, eds. The Blackwell companion to syntax, vol. 5. Malden, MA: Blackwell, 229-343.

Zanuttini, Raffaella. 1997. Negation and clausal structure: A comparative study of Romance languages. New York: Oxford University Press.

Zwart, C. Jan-Wouter. 1996. Verb clusters in Continental West Germanic Dialects. In Black \& Motapanyane, eds. 229-258. 


\section{Author's address}

Shannon A. Dubenion-Smith Western Washington University Department of Modern and Classical Languages 516 High St., Miller Hall 218C

Bellingham, WA 98225

USA

shannon.dubenion-smith@wwu.edu
Received: 12 February 2011

Revision invited: 20 April 2011

Revised version received: 3 November 2011

Accepted: 23 January 2012 
Copyright of Folia Linguistica is the property of De Gruyter and its content may not be copied or emailed to multiple sites or posted to a listserv without the copyright holder's express

written permission. However, users may print, download, or email articles for individual use. 